Kansas State University Libraries

New Prairie Press

\title{
Bereaved Elders: Transformative Learning in Late Life
}

Paul J. Moon

University of Georgia

Follow this and additional works at: https://newprairiepress.org/aerc

Part of the Adult and Continuing Education Administration Commons

(c) (1) (9)

This work is licensed under a Creative Commons Attribution-Noncommercial 4.0 License

\section{Recommended Citation}

Moon, Paul J. (2009). "Bereaved Elders: Transformative Learning in Late Life," Adult Education Research Conference. https://newprairiepress.org/aerc/2009/papers/43

This is brought to you for free and open access by the Conferences at New Prairie Press. It has been accepted for inclusion in Adult Education Research Conference by an authorized administrator of New Prairie Press. For more information, please contact cads@k-state.edu. 


\title{
Bereaved Elders: Transformative Learning in Late Life
}

\author{
Paul J. Moon, Ph.D. \\ University of Georgia, USA
}

\begin{abstract}
The purpose of this qualitative study was to understand older adults' transformative learning through bereavement in late life. Nine participants were engaged in semi-structured interviews. Data analysis affirmed that perspective transformation can occur through late life bereavement characterized by an oscillatory process shaped by biographical and life stage developmental contexts.
\end{abstract}

\section{Background and Statement of the Problem}

Bereavement is considered to be a principal source of distress in the human condition (Schaefer \& Moos, 2001). Older adults (aged 65 and over) face bereavement amid the backdrop of a greater accumulation of death events than younger adults, leaving them with an elevated susceptibility to bereavement overload (Moss, Moss, \& Hansson, 2001). Further, evidence exists of excessive suicide ideation in bereaved elders likely causing them to be at a "heightened risk for suicide relative to younger groups (Leenaars, 1995)" (Fortner \& Neimeyer, 1999, p. 404).

Yet other studies indicate that bereavement may also induce positive personal transformations (Hogan, Morse, \& Tason, 1996; Tedeschi \& Calhoun, 2004). Transformative Learning (TL) theory recognizes how paradigmatic shifts can occur as a result of crisis-like promptings (Mezirow, 1991). Indeed, Mezirow (1991) claimed death to be a stimulus towards epistemological changes in the learner. Moreover, Merriam and Clark (1993) point to how the more sudden accounts of personal transformations experienced by adults from their study were linked to painful experiences such as the death of a loved one. Though bereavement and grief have been considered in relation to TL (Danforth \& Glass, 2001; King, 2003), the age of participants in these studies have ranged mostly between young to middle adulthood. This is significant in that the nature of TL in older adulthood is little understood. In fact, Taylor (2000), as part of a comprehensive review of empirical research employing TL theory, posited "whether age is a factor in transformation is not known and needs to be better understood" (p. 289).

The purpose of my study was to understand older adults' TL through bereavement in late life. Research questions guiding this study were: (1) What do older adults specify as being transformed within them as a consequence of late life bereavement? (2) How does TL impact older adults' ongoing lives? (3) How do older adults describe the process of transformation? (4) What late life factors shape the TL process?

\section{Method}

A qualitative research approach was used to delve into older adults' epistemic alterations prompted by bereavement in late life. Purposeful sampling (Patton, 2002) was applied to locate individuals who richly informed the intent and aim of my study. Eight women and one man were interviewed. The oldest person was 82 years old and the youngest 71 years. All participants were Caucasian with the exception of one African American. Deaths included spouses, siblings, adult children, and parents, with time lapses since the date of death ranging from two to eleven years. There was also a mixture of gradual illness and abrupt loss. Deaths were reported to have occurred at home (some with hospice care) or in a hospital. Data collection was through semistructured interviews with open-ended questions. Interviews lasted between one to two hours and 
audio-tape recorded, accompanied by my field notes taken during sessions. Verbal narratives were transcribed and analyzed via the constant comparative method (Glaser \& Strauss, 1967).

\section{Findings}

Findings concerning elders' perspective changes and associated evidences included themes of greater consciousness of death issues, reprioritization of goals, and reevaluation of social relationships. Findings on the transformative process encompassed four major components (outlined below). And, findings on late life factors shaping the transformative process entailed issues of accumulated learning and life stage circumstances.

\section{Greater Consciousness of Death Issues}

This category manifested via older adults (a) responding to death issues with less dread, (b) admitting poignant awareness of personal mortality and the afterlife, and (c) expressing sensitization to the preciousness of life.

Response to death issues with less dread. Greater consciousness of death issues included changes in perspective and reaction to death itself. Josephine reported, "I am no longer surprised if someone else dies suddenly." Maureen expressed, "My feeling is that if I die tomorrow that's fine, it doesn't bother me, and I don't believe I felt that way beforehand."

Poignant awareness of personal mortality and the afterlife. In close relation to, yet differentiated from, responding to death issues with less dread is the poignant awareness of personal morality. Eve, upon her sister's death:

I changed a lot in the way I look about life and I try to stay ready to go because you never

know, I may be the next one going...I focused on that a lot...I used to think nothing will ever happen to me.

Gary pithily stated, “(My sister's death) made me more aware of my own mortality." Some elders emphasized poignant awareness of the hereafter or afterlife. Heather mused:

I hadn't given too much thought to...heaven.... But now I have to believe that because I

want to see these two guys (son and husband) again, and I have to believe there is some other plan for our lives...I have to believe there is and that came as a result of losing two people that were very, very close to me.

Sensitization to the preciousness of life. Elders reported a perspective change in values based on a greater consciousness of death. Betty professed, "Life's more precious to me now. I've learned to live everyday to the fullest because I may not have that opportunity again!' Gary expressed, "I think it (sister's death) just made me more conscious of how fortunate I've been...to get an education, have a career, married, have a child, grandchildren and so forth, which she did not."

\section{Reprioritization of Goals and Activities}

An outcome of transformation was a reprioritization of goals and activities. Betty reported, "I don't plan for tomorrow... anything can happen if we plan it and it'll fall through so I just don't believe in planning nothing." Eve's materialistic valuation shifted: "You've seen people that just focus their life on money...I used to be that way but not anymore; money's just another thing."

\section{Reevaluation of Intra-/Inter-Personal Relationships}

The vast majority of the elders transformed towards perceiving human relationships differently. Eve:

It has made me realize what life is and how to treat other people; it made me change completely.... Now, I have feelings for people and I give the shirt off my back to anybody 
who needed me but, you know, before then I didn't think about other people. Heather strongly sensed self-development through her late life bereavement:

I just grew and so I never want to go back to that space again....although I don't

welcome...going through what I went through with my husband it was a growing place

for me, it made me stronger.... I can take care of myself emotionally, physically,

financially, you know, that's the growing place; I think I'm still growing.

\section{Process of Transformation}

Four major components of the transformative process emerged from the data. The initial component was acute distress experienced by elders typically around the time of death. An ensuing component concerned elders reflecting upon selective life events such as past bereavement and particular aspects of the deceased. Other components were an emerging sense of change in perspectives and new behaviors.

Acute distress. All nine elders expressed significant distress due to deaths. Descriptive phrases included: "a shock type of reaction," "a real emptiness," "I was real lost," "it's just like something heavy hit me," "it was just like a dream," and "numbness."

Reflection. Past memories played an important part in elders' somber reflections in terms of assisting meaning-making of new death events. Reflection on past bereavement concerns comparing current bereavement with past bereavement. Reflection on particular aspects of the deceased describes elders' experience of being prompted with reflections that might be construed as fundamentally poignant, surfacing salient recollections related to the deceased symbolic of a broader set of meanings.

Emerging sense of change in perspectives. This component encompasses much of what was presented above. For elders to articulate these perspective changes came with some difficulty. Betty stated, "It's just a feeling you can't explain, there's no way you can explain it." Josephine exclaimed, "I believe there are some things I'll never forget..." and yet "I can't really put it into words I don't think....that's really hard to put it into words."

New behaviors. With the birth of altered views upon life the elders' actions changed accordingly. Heather expressed, "I think about things - "You need to do them now!"- I don't know whether if I'll have time later; I need to do it now if I'm going to do something." Marcie described, "Every time I speak with my children (now)....I'm very conscious that maybe this will be my last time to speak with them because we don't know what tomorrow brings and I talk with them about that."

\section{Late Life Factors Shaping Personal Transformation}

Accumulation of learning from earlier life experiences and life stage issues evidenced to further inform the TL dynamic. Identified issues could be interpreted as enriching or hindering elders' learning.

Accumulation of learning from earlier life experiences. This undeniable tenet of learning dynamics in old age overlaps with elders' comparative reflection upon past bereavements noted above. Heather's example:

I've been down this road, I know how hard it is....I'm very well aware of the process and the things that go along with it, and I just didn't want to do it but I knew I had to...I knew that there was no escaping grieving.

Others, like Gary, recounted a series of events that may have contributed to changes prompted by late life bereavement: "My mother died about 83 ...father died thereafter, so I had to take more responsibility for my sister....visiting her more and paying her bills....prior to then I wasn't mature enough to really take much responsibility or interest in her." An intuitive connection may 
be made between earlier life losses, the subsequent necessary alteration in responsibilities, the life experiences encountered through that time, and the fund of knowledge and recollections one brings to circumstances in later life.

Life stage issues. The complexity of a person's life stage positioning integrating with perspective shifts was seen in various modes, including differentiated social constellation and family role in late life. Holly remarked, "When you get old most of your friends... most of your relatives are gone...there are times when you want to talk to someone (about grief) but you don't want to talk with your kids." Elders' role in family progressed toward grandparent-hood, for example, situating them during grief in a family context different from earlier life periods. Proximity to personal death also seemed to provide existential urgency amid late life bereavement. Heather admitted, "I'm realizing I don't have much life ahead as I have behind." This stark realization appeared to have fostered reprioritization of elders' limited set of attention, hence shaping their TL.

\section{Discussion of Conclusions}

Three conclusions are made from the findings: (1) TL can occur in late life bereavement, (2) TL is a fluid and oscillatory process, and (3) TL is shaped by biographical and life stage developmental contexts.

TL can occur in Late Life Bereavement

TL through bereavement in late life was comprised of view changes of death-related issues and greater valuation of life. Death-related issues sparking transformation is not new (Courtenay, Merriam, Reeves, \& Baumgartner, 2000; King, 2003; Kinnier, Tribbensee, Rose, \& Vaughan, 2001). Increased valuation of the preciousness of life is also supported by existing literature (Tedeschi \& Calhoun, 2008). My study, however, did not show unidirectional movement towards preciousness of life but rather amid ongoing grief pangs was there significant re-consideration of the worthiness of life. Others confirm this sentiment of diversely relearning the world while grieving (Attig, 1996; Parkes, 2001).

TL is a Fluid and Oscillating Process

My study revealed a TL process differing from extant models that are rather linear and phasic. Elders' change process inhered a fluid dynamic congruent with other grief studies (Braun \& Berg, 1994; Danforth \& Glass, 2001). An oscillatory pattern was found resembling Stroebe and Schut's (1999) Dual Process Model of Coping with Bereavement. In my study, however, the oscillation concept arose from elders' lingering ambiguities and ambivalences. Though elders evidenced perspective transformation it was not without being tethered to 'baggage' from former ways of knowing. This oscillatory process seems to confound the notion of TL being irreversible in nature (Clark, 1991; Courtenay et al., 2000; Mezirow, 1991).

A further contestable point concerned rational discourse - an assumed notion and considered a fundamental tenet of TL (Taylor, 1998). Majority of elders in my study indicated a substantial lack of social dialogue in their transformation. Rather a proclivity towards in memoriam dialogue was discovered: elders conversationally engaging with memories of the dead. Stroebe, Gergen, Gergen, and Stroebe (1992), referring to another work, argued that "such dialogue serves the positive function of helping the bereaved clarify thoughts, deal with unfinished and emergent relationships, and prepare for the future" (p. 1210).

TL is Shaped by Biographical and Life Stage Developmental Contexts

The importance and strength of accumulated life experiences to late life are well supported (Aldwin, Sutton, Chiara, \& Spiro, 1996; Schaefer \& Moos, 2001). Tedeschi and 
Calhoun (2004) note that development of an individual's personal narrative and stress-induced growth may work in mutually fostering ways. The foundational necessity of life experiences is already recognized in TL (Mezirow, 1995). This aspect was seen in elders' comparative reflection juxtaposing past bereavement to those in late life. Such comparisons provided a frame of reference that served as experiential markers to assist in sensemaking of more current grief plights.

Life stage issues deemed to be particularly influential included a dwindling social network in old age (Coleman, 1990). This reduction of social opportunities redounds upon the dialogic exercise with caring others, in turn accentuating more solitary mechanisms of meaning-making (i.e., in memoriam dialogues). Proximity to elders' own death also shaped the contextual urgency of late life bereavement via increased mortality salience. This tensional component of old age has been mused upon by others (Erikson, Erikson, \& Kivnick, 1986; Havighurst, 1948). Elders' TL cycled between deaths of others cueing them of their own death and an augmented sense of their own death imbuing their perception of bereavement in the province of late life in various ways.

\section{Implications, Limitations and Recommendations}

Adult educators may use this study's results to expand their knowledge base on the commodious capacity of older adult learners to engage in TL and to construct learning programs for elders taking into account their oscillatory processing and reflecting patterns. Integrating death issues into learning activities for elders may be considered by educational gerontologists without fear. My study informs and challenges systemically held notions of how bereavement "ought" to look for elders. Further, older adults, and those who care for them, may find encouragement from elders' transformative experiences through bereavement in late life.

Recommendations for future research include broader sample diversity (gender, race, belief systems, etc.), along with longitudinal (for enduring factors) and cross-sectional (for comparative factors) study structures. Future research may also employ focus groups or group interview paradigm that may evince issues important to TL and grief theory, such as rational/social discourse, types of cognitive reflection, and benefit of support groups.

\section{References}

Aldwin, C. M., Sutton, K. J., Chiara, G., \& Spiro, A. (1996). Age differences in stress, coping, and appraisal: Findings from the normative aging study. Journal of Gerontology: Psychological Sciences, 51B, 4, P179-188.

Attig, T. (1996). How we grieve: Relearning the world. NY: Oxford University Press.

Braun, M. L., \& Berg, D. H. (1994). Meaning reconstruction in the experience of bereavement. Death Studies, 18, 105-129.

Clark, M. C. (1991). The restructuring of meaning: An analysis of the impact of context on transformational learning. Unpublished doctoral dissertation, Department of Adult Education, University of Georgia.

Coleman, P. (1990). Adjustment in later life. In J. Bond and P. Coleman (Eds.), Ageing in society, an introduction to social gerontology. London: Sage.

Courtenay, B. C., Merriam, S., Reeves, P., \& Baumgartner, L. (2000). Perspective transformation over time: A 2-year follow-up study of HIV-positive adults. Adult Education Quarterly, 50(2), 102-119.

Danforth, M. M., \& Glass, J. C., Jr. (2001). Listen to my words, give meaning to my sorrow: A study in cognitive constructs in middle-age bereaved widows. Death Studies, 25(6), 513-529. 
Erikson, J. M., Erikson, E. H., \& Kivnick, H. (1986). Vital involvement in old age. NY: Norton. Fortner, B. V., \& Neimeyer, R. A. (1999). Death anxiety in older adults: A quantitative review. Death Studies, 23, 387-411.

Glaser, B. G., \& Strauss, A. L. (1967). The discovery of grounded theory: Strategies for qualitative research. Chicago: Aldine Publishing Co.

Havighurst, R. J. (1948). Developmental tasks and education. NY: Longmans, Green and Company.

Hogan, N., Morse, J. M., \& Tason, M. C. (1996). Toward an experiential theory of bereavement. Omega, 33, 43-65.

King, K. P. (2003). Understanding adult learners amidst societal crisis: Learning and grief in tandem. Journal of Continuing Higher Education, 51(2), 13-25.

Kinnier, R. T., Tribbensee, N. E., Rose, C. A., \& Vaughan, S. M. (2001). In the final analysis: More wisdom from people who have faced death. Journal of Counseling \& Development, 79(2), 171-177.

Merriam, S. B., \& Clark, M. C. (1993). Learning from life experience: What makes it significant? International Journal of Lifelong Education, 12(2), 129-138.

Mezirow, J. (1991). Transformative dimensions of adult learning. San Francisco: Jossey Bass.

Mezirow, J. (1995). Transformation theory of adult learning. In M. R. Welton (Ed.), In defense of the life world (pp. 39-70). NY: State University of New York Press.

Moss, M. S., Moss, S. Z., \& Hansson, R. O. (2001). Bereavement and old age. In M. S. Stroebe, R. O. Hansson, W. Stroebe, \& H. Schut (Eds.), Handbook of bereavement research: Consequences, coping, and care. Washington, DC: American Psychological Association.

Parkes, C. M. (2001). Bereavement: Studies of grief in adult life ( $3^{\text {rd }}$ ed.). NY: Routledge/Taylor \& Francis.

Patton, M. Q. (2002). Qualitative research and evaluation methods ( $3^{\text {rd }}$ ed.). Thousand Oaks, CA: Sage.

Schaefer, J. A.,\& Moos, R. H. (2001). Bereavement experiences and personal growth. In M. S. Stroebe, R. O. Hansson, W. Stroebe, \& H. Schut (Eds.), Handbook of bereavement research: Consequences, coping, and care (pp. 145-167). Washington, DC: American Psychological Association.

Stroebe, M., Gergen, M., Gergen, K., \& Stroebe, W. (1992). Broken hearts or broken bonds: Love and death in historical perspective. American Psychologist,7, 1205-1212.

Stroebe, M., \& Schut, H. (1999). The dual process model of coping with bereavement. Death Studies, 23, 197-224.

Taylor, E. W. (1998). The theory and practice of transformational learning: A critical review. Columbus, OH: ERIC Clearinghouse on Adult, Career, \& Vocational Education (Information Series No. 374).

Taylor, E. (2000). Analyzing research on transformative learning theory. In J. Mezirow and Associates (Eds.), Learning as transformation: Critical perspectives on a theory in progress. San Francisco: Jossey-Bass.

Tedeschi, R. G., \& Calhoun, L. G. (2004). Posttraumatic growth: Conceptual foundations and empirical evidence. Psychological Inquiry, 15(1), 1-18

Tedeschi, R. G, \& Calhoun, L. G. (2008). Beyond the concept of recovery: Growth and the experience of loss. Death Studies, 32(1), 27-39. 